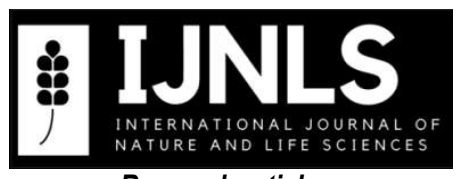

Research article

https://doi.org/10.47947/ijnls.840322
International Journal of Nature and Life Sciences (IJNLS)

https://www.dergipark.gov.tr/ijnls

e-ISSN: 2602-2397

Vol. 5 (1), June 2021, pp. 11-22

\title{
Molecular Phylogenetic Analyses of Vicia L. (Fabaceae) Taxa Growing in the Southeastern Anatolia Region Based on Chloroplast TrnL Sequences
}

\author{
Alevcan Kaplan ${ }^{1 *}$, Alaattin Selçuk Ertekin², Esra Gündüzer³ \\ ${ }^{1}$ Batman University, Sason Vocational School, Department of Crop and Animal Production, Batman, \\ Turkey,72060, orcid.org/0000-0001-6738-7527 \\ ${ }^{2}$ Ekinciler Street, Kalender Center, No: 9, Yenişehir, Diyarbakır, Turkey, 21100, orcid.org/0000-0003-2179-3778 \\ ${ }^{3}$ Gazi University, Life Sciences Application and Research Center, Ankara, Turkey, 06100, orcid.org/0000-0002- \\ 4474-7523 \\ *Corresponding author: kaplanalevcan@gmail.com
}

Received: 14 December 2020, Accept: 02 January 2021, Published Online: 01 June 2021

\begin{abstract}
In the current study, some natural Vicia L. taxa growing naturally in the Southeast Anatolia Region were investigated from the point of view of molecular phylogenetic. For this purpose, transfer ribonucleic acid Leucine (trnL) was sequenced in order to study the phylogenetic relationships of the Vicia L. species. Lathyrus inconspicuous L. var. inconspicuous and Lathyrus cassius Boiss. were used as an outgroup. The length of the trnL area was determined approximately as $269-534 \mathrm{bp}$. The trnL sequences were submitted to the NCBI database and accession numbers received. We obtained information about the point mutations, as well as the protected and the changing characters. The taxa distinguished in the section level were separated and also grouped in terms of proximity on the phylogenetic tree (sect. Narbonensis, sect. Lathyroides, sect. Peregrinae, sect. Vicia, sect. Lentopsis). While, sect. Hypechusa, sect. Ervilia and sect. Cracca were not detailed to a great level of informativity. The data acquired were observed to be greatly reliable in terms of their ability to be used in solving taxonomical problems of the Vicia L. taxa.
\end{abstract}

Key words: cpDNA, Fabaceae, molecular phylogeny, sequencing, Vicia L.

\section{Introduction}

The legume family includes $720-730$ genera and about 19.500 species. There are 69 genera in Turkey containing 1128 taxa and including 375 endemic taxa (Simpson, 2012). The genus Vicia is a member of the Vicieae legume tribe of Papilionoideae, and the genus itself has proven to be a popular group to study (Frediani et al., 2004). Vicia L. comprises about 210 species, is considered to have 22 divisions in two subgenus (Vicia and Vicilla), and is widely distributed throughout Europe and Asia ( 110 species) North America ( 20 species) and Africa ( 15 species) (Kupicha, 1976; Weber and Schifino-Wittmann, 1999; Roze and Rurane, 2013). The genus 
was originally localized to the Mediterranean and Irano-Turanian regions (Kupicha, 1981). The Mediterranean region is the main diversity center (Gunn, 1980; Naranjo et al., 1998). In Turkey, 64 species, 22 subspecies and 18 varieties of this genus have been recorded (Davis, 1970; Vural, 2000; Inceer and Ayaz, 2005; Başbağ et al., 2013).

Vicia L. species are morphologically diverse and the morphological approach find it quite difficult to account for all the genetic variation that exist. Previous papers have reported morphological, anatomical, cytological, karyological and biochemical and molecular (although this has not been sufficient) data in order to elucidate the relationships within the Vicia genus (Frediani et al., 1992; Cremonini et al., 1998 a, b; Maggini et al., 1991; Venora et al., 2000; Tabur et al., 2002; Navratilova et al., 2003; Bryant and Hughes, 2011; Kahraman et al., 2013). Recently, plant organelle genomes (chloroplast and mitochondrial DNA) have been widely used for population genetics studies and in order to reveal phylogenetic relationships (Soltis et al., 1992). Non-coding regions in the chloroplast genome are often preferred for molecular systematic and plant-related population genetic studies (Shaw et al., 2006). DNA regions that are not coded show a high degree of mutation. For this reason, they are widely used to show evolutionary relationships (Taberlet et al., 1991). One of the non-coding regions in the chloroplast DNA is tRNA and this is used in determining evolutionary relationships. The most frequently used of these regions are $\operatorname{trnT}$ (UGU) - $\operatorname{trn} L$ (UAA) IGS, $\operatorname{trn} L 5$ '-trnL3 'intron and $\operatorname{trn} L$ (UAA) - $\operatorname{trnF}$ (GAA) IGS regions (Taberlet et al., 1991; Kelchner, 2000). This study aimed to use transfer ribonucleic acid Leucine (trnL) as the differential region to examine the relationships within the Vicia genus growing in the Southeast Anatolian Region.

\section{Materials and Methods}

\subsection{Plant material}

Plant material was collected from different localities of the study area from April to May, which is the vegetation periods of plants from natural habitats and identified according to the diagnostic morphological characteristics described in the Flora of Turkey and the East Aegean Islands (Davis, 1970). The study area is located in the Southeastern Anatolia Region. (Adıyaman, Batman, Diyarbakır, Gaziantep, Mardin, Siirt, Şanlıurfa) covers the area. Species were included in the eight different sections; Cracca S. F. Gray, Ervilia (DC) Link, Lentopsis Kupicha, Peregrinae Kupicha, Lathyroides (Buchenau) Tzvel, Hypechusa (Alef.) Aschers and Graebner, Vicia L. and Narbonensis (Radzhi) Maxted. To construct the phylogenetic relationships of the Vicia genus, we analyzed sequences of $t r n L$ regions from a total of 22 specimens and 25 taxa. Lathyrus cassius Boiss. and Lathyrus inconspicuous $L$. were used as out-group. DNA sequences of the studied taxa were entered into the $\mathrm{NCBI}$ database and an accession number was obtained for each species. Plant deposited under suitable conditions at the Herbarium of the Department of Biology (DUF), Faculty of Science and Art, Dicle University. 
Table 1. The taxa of Vicia L. studied and their collecting sites, section, accession number and voucher name and herbarium number.

\begin{tabular}{|c|c|c|c|c|c|}
\hline No & Taxon names & Section & Location & $\begin{array}{l}\text { Accession } \\
\text { number }\end{array}$ & $\begin{array}{l}\text { Voucher name and } \\
\text { herbarium number }\end{array}$ \\
\hline 1 & V. narbonensis L. var. narbonensis & Narbonensis & $\begin{array}{l}\text { Batman, Batman University, central } \\
\text { campus, } 570 \mathrm{~m} .\end{array}$ & MN862284 & A.Kaplan DUF 90 \\
\hline 2 & V. hybrida L. & Hypechusa & $\begin{array}{l}\text { Batman, Batman University, central } \\
\text { campus, } 570 \mathrm{~m} \text {. }\end{array}$ & MN862285 & A.Kaplan DUF 88 \\
\hline 3 & $\begin{array}{l}\text { V. villosa Roth subsp. varia (Host) } \\
\text { Corb. }\end{array}$ & Cracca & $\begin{array}{l}\text { Adıyaman, Bozova to Adıyaman, } 18.5 \mathrm{~km} \text {, } \\
589 \mathrm{~m} \text {. }\end{array}$ & MN862286 & A.Kaplan DUF 48 \\
\hline 4 & V. mollis Boiss. \& Hausskn. & Hypechusa & $\begin{array}{l}\text { Adıyaman, Hilvan to Bozova, Külünçe } \\
\text { village, } 5 \mathrm{~km}, 600 \mathrm{~m}\end{array}$ & MN862287 & A.Kaplan DUF 40 \\
\hline 5 & V. galeata Boiss. & Hypechusa & $\begin{array}{l}\text { Adıyaman, Hilvan to Bozova, Külünçe } \\
\text { village, } 5 \mathrm{~km}, 600 \mathrm{~m} \text {. }\end{array}$ & MN862288 & A.Kaplan DUF 44 \\
\hline 6 & V. sativa L. subsp. sativa & Vicia & $\begin{array}{l}\text { Diyarbakır, Dicle University campus, } \\
\text { Bakbako stream around, } 630-640 \mathrm{~m} \text {. }\end{array}$ & MN862289 & A.Kaplan DUF 82 \\
\hline 7 & $\begin{array}{l}\text { V. sativa L. subsp. nigra L. (Ehrh.) } \\
\text { var. nigra L. (Ehrh.) }\end{array}$ & Vicia & $\begin{array}{l}\text { Diyarbakır, Çermik to Çüngüş, 6-7 km, } 703 \\
\text { m. }\end{array}$ & MN862290 & $\begin{array}{l}\text { A.Kaplan \& A.S.Ertekin } \\
\text { DUF } 35\end{array}$ \\
\hline 8 & $\begin{array}{l}\text { V. michauxii Sprengel. var. } \\
\text { stenophylla Boiss. }\end{array}$ & Peregrinae & Şanlıurfa, Şanlıurfa to Suruç, $18 \mathrm{~km}, 666 \mathrm{~m}$. & MN862291 & A.Kaplan DUF 08 \\
\hline 9 & $\begin{array}{l}\text { V. monantha Retz subsp. } \\
\text { monantha Retz. }\end{array}$ & Cracca & Şanlıurfa, Akçakale, 382 m. & MN862292 & A.Kaplan DUF 09 \\
\hline 10 & V. anatolica Turril. & Hypechusa & Mardin, Exit of Mardin 2 km, 1095m. & MN862293 & A.Kaplan DUF 12 \\
\hline 11 & V. peregrina $\mathrm{L}$. & Peregrinae & Siirt, Çatılı village, $1475 \mathrm{~m}$. & MN862294 & A.Kaplan DUF 73 \\
\hline 12 & $\begin{array}{l}\text { V. noeana Reuter ex Boiss var. } \\
\text { noeana Reuter ex Boiss. }\end{array}$ & Hypechusa & $\begin{array}{l}\text { Diyarbakır, Ergani to Çermik, } 13 \text { km, } 870 \text { - } \\
875 \text { m. }\end{array}$ & MN862295 & $\begin{array}{l}\text { A.Kaplan \& A.S.Ertekin } \\
\text { DUF } 16\end{array}$ \\
\hline 13 & $\begin{array}{l}\text { V. sericocarpa Fenzl. var. } \\
\text { sericocarpa Fenzl. }\end{array}$ & Hypechusa & $\begin{array}{l}\text { Diyarbakır, Ergani to Çermik } 13 \text { km, } 870- \\
875 \text { m. }\end{array}$ & MN862296 & $\begin{array}{l}\text { A.Kaplan \& A.S.Ertekin } \\
\text { DUF } 18\end{array}$ \\
\hline 14 & V. lathyroides L. & Lathyroides & $\begin{array}{l}\text { Diyarbakır, Çermik to Çüngüş, } 11.5-12 \text { km, } \\
905 \text { m. }\end{array}$ & MN862297 & $\begin{array}{l}\text { A.Kaplan \& A.S.Ertekin } \\
\text { DUF } 39\end{array}$ \\
\hline 15 & V. ervilia (L.) Willd. & Ervilia & $\begin{array}{l}\text { Diyarbakır, Ergani to Çermik, } 16-17 \text { km, } \\
880 \mathrm{~m}\end{array}$ & MN862298 & $\begin{array}{l}\text { A.Kaplan \& A.S.Ertekin } \\
\text { DUF } 21\end{array}$ \\
\hline 16 & V. galilaea Plitm. Et. Zoh. & Narbonensis & Diyarbakır, Çermik to Siverek, 1 km, $732 \mathrm{~m}$ & MN862299 & $\begin{array}{l}\text { A.Kaplan \& A.S.Ertekin } \\
\text { DUF } 32\end{array}$ \\
\hline 17 & $\begin{array}{l}\text { V. cracca L. subsp. stenophylla } \\
\text { Vel. }\end{array}$ & Cracca & $\begin{array}{l}\text { Adıyaman, Ferryboat to Siverek, } 4 \text { km, } \\
588 \mathrm{~m}\end{array}$ & MN862300 & A.Kaplan DUF 56 \\
\hline 18 & V. palaestina Boiss. & Cracca & $\begin{array}{l}\text { Diyarbakır, Çermik to Çüngüş } 11.5-12 \text { km, } \\
905 \text { m. }\end{array}$ & MN862301 & $\begin{array}{l}\text { A.Kaplan \& A.S.Ertekin } \\
\text { DUF } 38\end{array}$ \\
\hline 19 & V. lutea var. hirta (Balbis) Lois. & Hypechusa & Diyarbakır, Devegeçidi picnic area, 732 m. & MN862302 & $\begin{array}{l}\text { A.Kaplan \& A.S.Ertekin } \\
\text { DUF } 59\end{array}$ \\
\hline 20 & V. esdraelonensis Warb. \& Eig & Hypechusa & $\begin{array}{l}\text { Diyarbakır, the way of Bilgekışla, } 3.5 \mathrm{~km} \text {, } \\
740 \mathrm{~m} \text {. }\end{array}$ & MN862303 & $\begin{array}{l}\text { A.Kaplan \& A.S.Ertekin } \\
\text { DUF } 60\end{array}$ \\
\hline 21 & $\begin{array}{l}\text { V. villosa Roth subsp. eriocarpa } \\
\text { (Hausskn) P.Ball. }\end{array}$ & Cracca & $\begin{array}{l}\text { Adıyaman, Hilvan to Bozova, Külünçe } \\
\text { village, } 5 \mathrm{~km}, 600 \mathrm{~m} \text {. }\end{array}$ & MN862304 & A.Kaplan DUF 41 \\
\hline 22 & $\begin{array}{l}\text { V. sativa L. subsp. amphicarpa } \\
\text { (Dorth.) Aschers. \& Graebn. }\end{array}$ & Vicia & $\begin{array}{l}\text { Diyarbakır, Dicle University campus, } 630 \text { - } \\
640 \mathrm{~m} .\end{array}$ & MN862305 & A.Kaplan DUF 80 \\
\hline 23 & V. assyriaca Boiss. & Hypechusa & $\begin{array}{l}\text { Şanlıurfa, Siverek Avurtepe } \\
\text { village, Otlu avenue,1080 m. }\end{array}$ & MN862306 & A.S.Ertekin DUF 79 \\
\hline 24 & V. montbretii Fisch. \& C.A.Mey. & Lentopsis & $\begin{array}{l}\text { Şanlıurfa, Siverek Avurtepe village, Otlu } \\
\text { avenue, } 1080 \mathrm{~m} .\end{array}$ & MN862307 & A.S.Ertekin DUF 78 \\
\hline 25 & V. caesarea Boiss. \& Bal. & Lentopsis & $\begin{array}{l}\text { Siirt, Şirvan to Madenköy, } \\
4-5 \mathrm{~km}, 1020 \mathrm{~m} \text {. }\end{array}$ & MN862308 & A.S.Ertekin DUF 184 \\
\hline 26 & Lathyrus cassius Boiss. & Lathyrus & $\begin{array}{l}\text { Diyarbakır, the way of Bilgekışla, } 3.5 \text { km, } \\
740 \mathrm{~m} \text {. }\end{array}$ & MN862309 & A.S.Ertekin DUF 4241 \\
\hline 27 & Lathyrus inconspicuous L. & Linearicarpus & $\begin{array}{l}\text { Gaziantep, Islahiye Bahçe to Gaziantep, } 22 \\
\text { km. }\end{array}$ & MN862310 & A.S.Ertekin DUF 5249 \\
\hline
\end{tabular}

\subsection{DNA extraction, $P C R$, sequencing, sequence alignment and phylogenetic analyses}

Total genomic DNA were isolated from dried and stored at room temperature leaf tissues using the Lefort et al. (1998) method. The purity and quantity determinations of extracted DNAs were determined by NanoDrop 1000c UV-Vis Spectrophotometer (Thermo Scientific) at $A_{260} / A_{280} \mathrm{~nm}$. The isolated DNA samples were checked in $1 \%$ agarose gel electrophoresis (Figure 1). Specific primer pairs were used to amplify (amplification) the targeted region on genomic DNA. Amplification of $t r n L$ region was carried out by using primer 
pairs trnc 5' CGA AAT CGG TAG ACG CTA CG 3' (Forward) / trnd 5' GGG GAT AGA GGG ACT TGA AC 3' (Reverse) (White et al., 1990).

DNA amplification was performed in a $50 \mu$ volume mixture containing genomic DNA (100 $\mathrm{ng} / \mu \mathrm{l}), 10 \mathrm{X}$ PCR Buffer, MgCl2 (25 mM), dNTP mixture (25 mM), selected primer pair $(50 \mu \mathrm{M})$, Taq polymerase $(5 \mathrm{u} / \mu \mathrm{l})$ and sterile water $\left(\mathrm{ddH}_{2} \mathrm{O}\right)$. PCR reaction of each region consisted of almost same amount of Buffer (5 $\mu$ l), DNA (1 $\mu$ l), MgCl2 $(1,5 \mu l)$, dNTP $(1 \mu l)$, each primer (forward and reverse) $(1,5 \mu l)$ and Taq polymerase $(0.3 \mu l)$. PCR amplification was started with 2 min initial denaturation at $94{ }^{\circ} \mathrm{C}$, and terminated with 5 min at $72{ }^{\circ} \mathrm{C}$. Each reaction ended with a final $4^{\circ} \mathrm{C}$ hold step and consisted of 35 cycle numbers. Each reaction cycle consisted of denaturation step at $94{ }^{\circ} \mathrm{C}$ for $20 \mathrm{sec}(1 \mathrm{~min})$, annealing step at $57^{\circ} \mathrm{C}$ for $30 \mathrm{sec}$ and elongation step at $72{ }^{\circ} \mathrm{C}$ for $301 \mathrm{~min}$. Amplicons were visualized by electrophoresis on $2 \%$ agarose gels (Figure 2). After purification, products were sequenced in both directions using Applied 3130 Genetic Analyzer automated sequencer. All sequence chromatograms were opened using DNA dragon software. Ambiguous sites were checked manually and corrected by comparing the strands. Sequences of $t r n L$ region have been deposited in NCBI database for further studies.

Molecular Evolutionary Genetics Analysis software (MEGA 5.1; [Beta 2] is used to measure total nucleotide length (base pair, bp) (Table 2). DNA sequences were aligned via the Clustal W program. The sequence data was analyzed by using the UPGMA method (Figure 3) based on the Kimura model (Kimura, 1980) and bootstrap analysis with 1000 replications (Felsenstein, 1985). The bootstrap value ranges from $0 \%$ to $100 \%$. According to the Kress et al. (2005), bootstrap support values, it was defined as $>85 \%$ very strong, $70-85 \%$ strong, $50-70 \%$ weak and $<50 \%$ very weak. $70 \%$ or greater bootstrap support is often associated with the identification of the correct phylogeny. If the bootstrap support for a certain branch is below $50 \%$; It is concluded that the relationship between the species is not fully clarified and the branching model is not determined and as a result, this branch will be determined in the tree as a fork (polytomy = uncertainty point) rather than a single node (Freeman and Herron, 1999).

\section{Results}

\subsection{Observation of amplification products}

When PCR was performed on gDNA samples of targeted species, the presence of bands was visualized by $1 \%$ agarose gel electrophoresis (Figure 1). And then amplicons ( $t m L$ region) were visualized by electrophoresis on $2 \%$ agarose gels (Figure 2 ). 


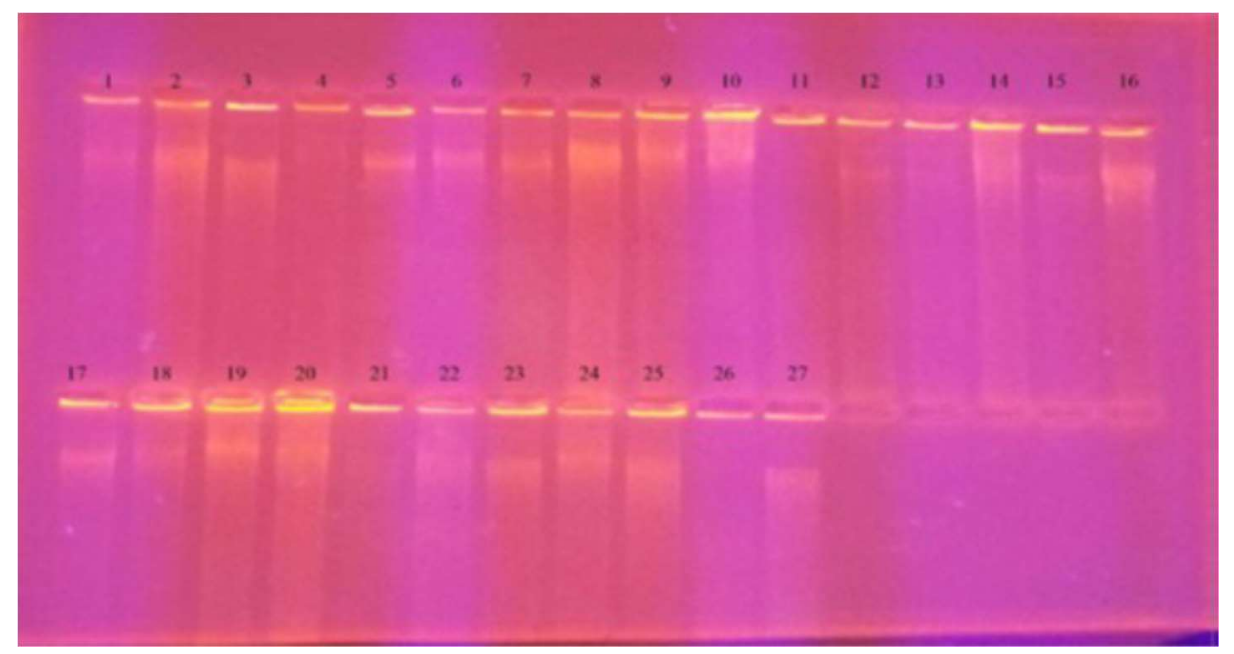

Figure $1.1 \%$ gel image of Vicia species PCR products; 1) V. narbonensis var. narbonensis 2) V. hybrida 3) V. villosa subsp. varia 4) V. mollis 5) V. galeata 6) V.sativa subsp. sativa 7) V. sativa subsp. nigra var. nigra 8) V. michauxii var. stenophylla 9) V. monantha subsp. monantha. 10) V.anatolica 11) $V$. peregrina 12) V. noeana var. noeana 13) V. sericocarpa var. sericocarpa 14) V. lathyroides 15) V. ervilia 16) V. galilaea 17) V. cracca subsp. stenophylla 18) V. palaestina 19) V. lutea var. hirta 20) V. esdraelonensis 21) V. villosa subsp. eriocarpa 22) V. sativa subsp. amphicarpa 23) V. assyriaca 24) V. montbretii 25) V. caesarea 26) Lathyrus cassius 27) Lathyrus inconspicuous.

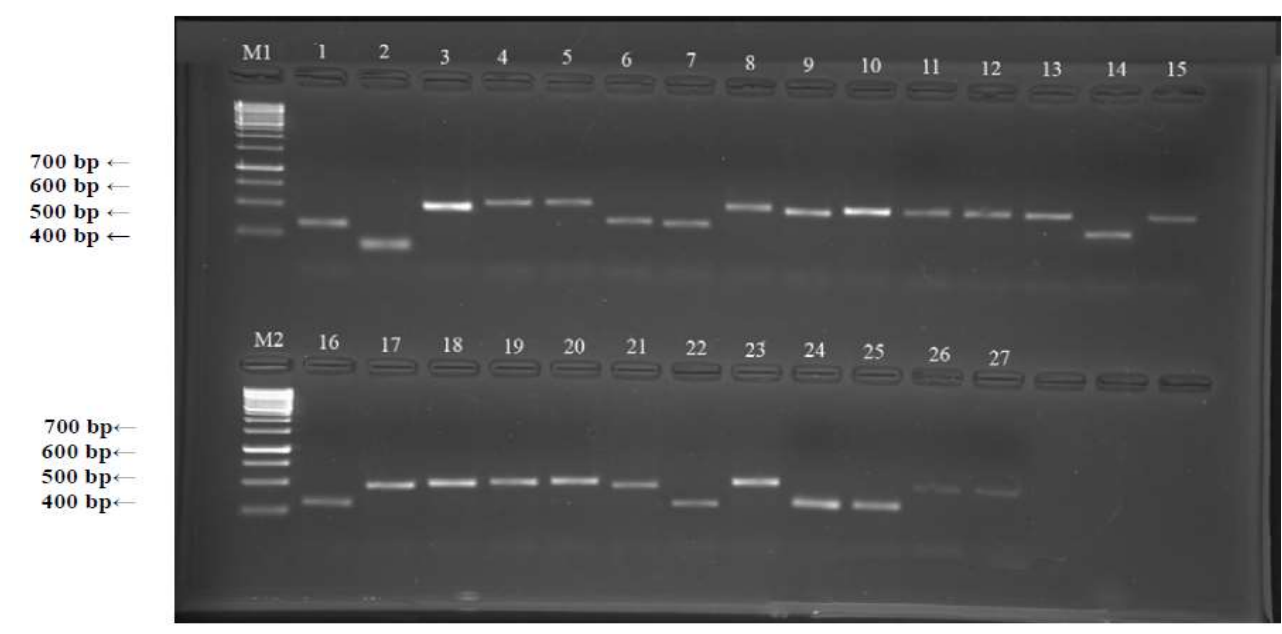

Figure 2. Nuclear DNA of the Vicia species trnL region image of agarose gel (2\%); 1) V. narbonensis var. narbonensis 2) V. hybrida 3) V. villosa subsp. varia 4) V. mollis 5) V. galeata 6) V.sativa subsp. sativa 7) V. sativa L. subsp. nigra var. nigra 8)V. michauxii var. stenophylla 9) V. monantha subsp. monantha 10) $V$. anatolica 11) V. peregrina 12) V. noeana var. noeana 13) V. sericocarpa var. sericocarpa 14) V. lathyroides 15) V. ervilia 16) V. galilaea 17) V. cracca subsp. stenophylla 18) V. palaestina 19) V. lutea var. hirta 20) V. esdraelonensis 21) V. villosa subsp. eriocarpa 22) V. sativa subsp. amphicarpa 23) V. assyriaca 24) V. montbretii 25) V. caesarea 26) Lathyrus cassius 27) Lathyrus inconspicuous.

\subsection{Nucleotide sequences of the trnL region}

The base ratios obtained from approximately $408 \mathrm{bp}$ of which $\operatorname{trn} L$ gene were analyzed in the series are given in Table 1. When Table 2 is examined trnL region sizes varied from 269 bp (Vicia narbonensis var. narbonensis and Vicia caesarea) to $534 \mathrm{bp}$ (Vicia esdraelonensis). It appears to be A: 27,3 \%, G: 16,4 \%, C: 17,2 $\%, T(U): 39,1 \%$. DNA sequences related to the samples are G - C ratio (33,6 \%), A - T ratio (66,4 \%). The DNA sequences of the samples are relatively rich in $A-T$, the $G-C$ ratio is less. 
Table 2. trnL region sizes in Vicia L. and Lathyrus L. (outgrup) taxa.

\begin{tabular}{lccccc}
\hline Species name & T(U) & C & A & G & Total \\
\hline Vicia narbonensis var. narbonensis & 36,1 & 19,0 & 27,9 & 17,1 & 269,0 \\
Vicia hybrida & 40,3 & 16,7 & 26,7 & 16,3 & 461,0 \\
Vicia villosa subsp. varia & 38,8 & 17,4 & 29,1 & 14,7 & 443,0 \\
Vicia mollis & 41,0 & 15,0 & 27,9 & 16,2 & 427,0 \\
Vicia galeata & 41,1 & 14,7 & 28,7 & 15,4 & 428,0 \\
Vicia sativa subsp. sativa & 36,3 & 19,0 & 25,9 & 18,7 & 347,0 \\
Vicia sativa subsp. nigra var. nigra & 38,4 & 19,5 & 25,3 & 16,8 & 292,0 \\
Vicia michauxii var. stenophylla & 39,7 & 17,4 & 27,8 & 15,1 & 478,0 \\
Vicia monantha subsp. monantha & 38,7 & 17,2 & 28,8 & 15,3 & 431,0 \\
Vicia anatolica & 40,6 & 17,0 & 27,5 & 15,0 & 488,0 \\
Vicia peregrina & 41,0 & 15,7 & 28,1 & 15,2 & 402,0 \\
Vicia noeana var. noeana & 41,4 & 16,1 & 26,9 & 15,6 & 435,0 \\
Vicia sericocarpa var. sericocarpa & 41,0 & 15,4 & 28,2 & 15,4 & 415,0 \\
Vicia lathyroides & 36,0 & 18,9 & 26,3 & 18,9 & 350,0 \\
Vicia ervilia & 40,3 & 16,6 & 27,1 & 15,9 & 409,0 \\
Vicia galilaea & 34,9 & 19,0 & 27,5 & 18,7 & 327,0 \\
Vicia cracca subsp. stenophylla & 38,7 & 16,7 & 28,6 & 16,0 & 426,0 \\
Vicia palaestina & 39,2 & 16,2 & 28,4 & 16,2 & 444,0 \\
Vicia lutea var. hirta & 39,8 & 16,7 & 27,8 & 15,7 & 497,0 \\
Vicia esdraelonensis & 39,1 & 16,7 & 27,3 & 16,9 & 534,0 \\
Vicia villosa subsp. eriocarpa & 37,6 & 17,6 & 28,6 & 16,3 & 490,0 \\
Vicia sativa subsp. amphicarpa & 38,0 & 19,2 & 25,7 & 17,0 & 276,0 \\
Vicia assyriaca & 41,2 & 15,7 & 26,9 & 16,2 & 413,0 \\
Vicia montbretii & 35,7 & 20,9 & 24,3 & 19,1 & 325,0 \\
Vicia caesarea & 38,3 & 20,8 & 23,0 & 17,8 & 269,0 \\
Lathyrus cassius & 38,0 & 17,4 & 26,8 & 17,8 & 511,0 \\
Lathyrus inconspicuous & 40,0 & 16,3 & 26,3 & 17,4 & 448,0 \\
Avg. & 39,1 & 17,2 & 27,3 & 16,4 & 408,7 \\
\hline
\end{tabular}

\subsection{Molecular phylogeny}

Phylogenetic associations and genetic diversity data were made with Mega (Molecular Evolutionary Genetics Analysis) 5. 1 Beta 2 software using sequence analysis results. Unweighted pair group method with arithmetic mean (UPGMA) method was used during the drawing of the phylogenetic tree (Figure 3). In order to increase the reliability of the obtained tree, bootstrap analysis with 1000 replications was preferred. The percentage of each branch shows how much that branch is supported. If the branch's reliability rate is below 50 $\%$, the program qualifies this branch as very weak and collapses that branch, and the empty branch resulting from the collapsed branch is called a polytomy. Since the branching model cannot be determined in collapsed branches, no interpretation can be made about the relationship between taxa. It can be said that only this branch has created a polytomy. 


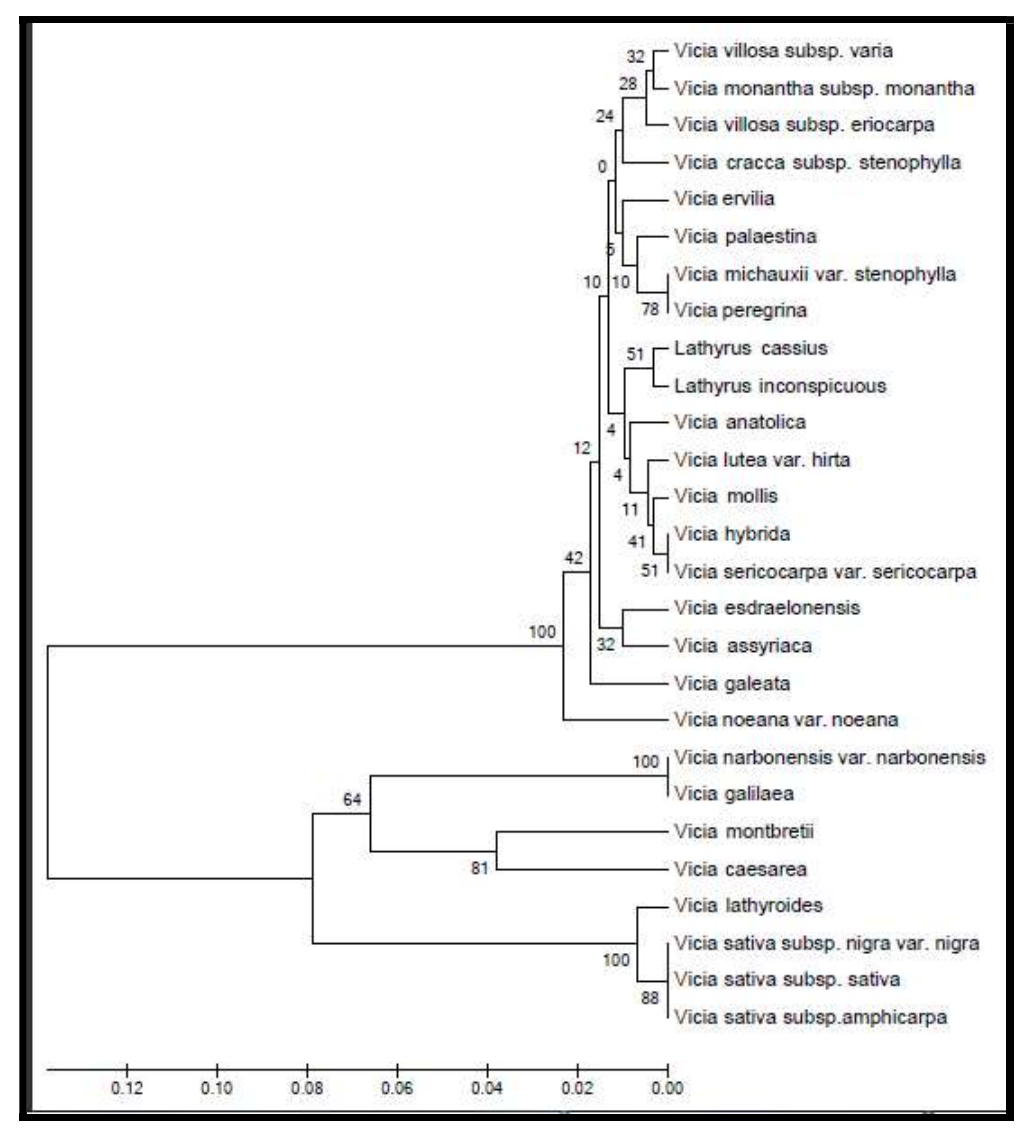

Figure 3. Phylogenetic tree of Vicia species based on (UPGMA) analysis of the trnL region. Lathyrus cassius and Lathyrus insconspicuous were used as a outgroup. Bootstrap analysis of UPGMA was based on 1000 replicates. Percentage of each branch shows the support rate of that branch (Bootstrap value).

\section{Discussion}

DNA sequencing technologies and recent advances in molecular biology enable us to characterize the genomes of organisms and many ongoing genome projects for various species are providing valuable insight into their biology and uses. In this context, many molecular studies of the Vicia genus have been carried out. Different coding and non-coding regions from both nuclear and chloroplast DNAs have been studied. For instance, phylogenetic relationships between Vicia faba (Fabaceae) and related species $\operatorname{trn} L$ sequence (Fennel et al., 1998), nuclear ribosomal DNA internal transcribed spacer (ITS) (Foladi et al., 2013) and matK (Steele and Wojciechowski, 2003) are, some of the molecular systems which have been extensively used for molecular systematic studies.

In this study, we chose to use the transfer ribonucleic acid Leucine (trnL) region of nuclear DNA. The reasons for using chloroplast in plant phylogenetic studies are as follows: the structural stability of cpDNA, that it is haploid (n), that it generally has a uniperantal transfer, that it is non-recombinant (Small et al., 2004). In the unweighted pair group method with arithmetic mean (UPGMA) tree obtained in the present study (Figure 3), it was observed that Lathyrus species used as an outgroup were nested within other species and this branch was supported with a bootstrap value of $51 \%$. The ingroup consists of two main clades. Using the data from Figure 3 , the branch with $V$. narbonensis var. narbonensis and $V$. galilaea (sect. Narbonensis) species was supported with a bootstrap value of $100 \%$. Molecular data is based on sequences of the trnL with high bootstrap values.In many 
studies (Enneking and Maxted,1995; Fennel et al., 1998; Potokina, 1999; Schaefer et al., 2012), the species belonging to sect. narbonensis have been studied in the same branch. These results are in line with those of the current study. Schaefer et al. (2012), reported that the section was monophyletic. Our study supports the assertion that section is monophyletic. The species belonging to sect. Lentopsis (V. montbretii, V. caesarea) were supported with a bootstrap value of $81 \%$. Schaefer et al. (2012), in their study, sect. lentopsis examined the species in the tree of maximum likelihood in the same branch. Binzat (2012), Foladi, et al. (2003), Schaefer et al. (2012) also studied the molecular phylogeny of Vicia species in parallel with our work. The branch where V. sativa subsp. sativa, V. sativa subsp. nigra var. nigra, V. sativa. subsp. amphicarpa species are found is supported a bootstrap value with $88 \%$ and this value shows us that we have achieved a meaningful result. Molecular data based on sequences of the trnL with high bootstrap values, support the placement of these species in section $V$. lathyroides, which was connected to this branch with a high bootstrap value, for example a $100 \%$. Van de Wouv et al. (2001), found that, V. sativa subsp. amphicarpa and V. sativa subsp. nigra var. nigra were located close to each other, while $V$. sativa subsp. sativa was located farther away in the UPGMA phylogenetic tree they obtained. Potokina, (1999) reported that the $V$. sativa complex coexists in the dendograms they obtained in their study. Leht, (2009), Potokina, (1999) and Schaefer et al. (2012) reported that this section is not monophyletic but polyphyletic. However, Potokina et al. (1999), examined V. lathyroides species as a separate branch in their study and supported the branch where this species was located with a value of $53 \%$. They also found it close to the Vicia section in all the trees they created. Jaaska, (2008) and Leht, (2009) reported that they found the species to be close to the Vicia section. Although the bootstrap value of the $V$. lathyroides species is low, it has established a close connection with the sect. Vicia as in the studies mentioned above. Schaefer et al. (2012) determined that the section was not monophyletic. The results we obtained in our study support the current studies.

The branch with the highest bootstrap value in the group was the branch with $V$. michauxii var. stenophylla and $V$. peregrina species, which was supported with a bootstrap value of $78 \%$. Molecular data based on sequences of the trnL with high bootstrap values, supports the placement of these species in this section. In many studies (Fennel et al., 1998; Potokina et al., 1999; Leht, 2009; Emre, 2011; Schaefer et al., 2012), these species have been found in the same branch and examined in the Peregrinae section. Schaefer et al. (2012) in their study, they found that the section was monophyletic. This result is in line with our study.

As is well known, unrooted trees are obtained with bootstrap method. The values on the branches of the trees are used to determine the most statistically reliable branches. The percentage ratio of each branch indicates how much that branch is supported. If the reliability rate of the branch is below $50 \%$, the program considers this branch very weak and collapses that branch, and the empty branch resulting from the collapsed branch is called polytomy. Since the branching model in collapsed branches cannot be determined, no comment can be made on the relationship between taxa. It can only be said that this branch has created a polytomy. In the phylogenetic tree that we have obtained, V. villosa subsp. varia, V. villosa subsp. eriocarpa, V. cracca subsp. stenophylla, V. monantha subsp. monantha, V. palaestina (sect. Cracca), V. ervilia (sect. Ervilia) V. lutea var. hirta, V. galeata, V. assyriaca, $V$. esdraelonensis, $V$. noeana var. noeana, $V$. hybrida, $V$. mollis, $V$. anatolica, $V$. sericocarpa var. 
sericocarpa (sect. Hypechusa) were species branches where the species were found to have collapsed. Polytomy was observed since the reliability value was below $50 \%$. Therefore, the parser did not provide any information. In the current study, these taxa were found to be problematic, and showed a random distribution in phylogenetic trees, and were thus supported by a low bootstrap value. The tree that we created was not successful in separating these species. This may be because the taxa are actually differentiated from a single ancestral species or because of conflicting or missing data. The occurrence of polytomies in phylogenetic analysis may indicate an interesting evolutionary history that needs further research. In addition, molecular characters are more objective than morphological characters, but they are not accurate. Polymorphisms and uncertainties may arise in determining the basis for DNA sequence data. It may not be easily understood, especially if the sequences between taxa are very different when making sequence alignments. Also, the possibilities of paralogy arising from ancestral gene duplication or hybridization can cause confusion when comparing homologous sequences (Simpson, 2012). The genetic diversity of the species is already due to the variation in genes and their recombination (Lorenzetti, 1994, Lorenzetti, 1996). In the current study, such mutations occurring in species were indicative of genetic diversity and such differences manifested themselves in the dendogram we obtained. In the future, we propose that only studies on these taxa (various molecular marker systems such as biochemical, AFLP, RFLP, ISSR, SSR) should be conducted in detail. We also consider that such studies could study the MatK region in the chloroplast genome. It should not be forgotten that each method often leads to a different result. Expecting a specific and accurate result (a tree) is not appropriate anyway; there are no perfect trees, but some are useful.

This study attempted to examine Vicia L. species morphologically and molecularly in a flexible way and to eliminate the deficiencies in the literature. It is our duty to carefully conserve the gene resources of the many Vicia L. species, which are almost as old as human history are and which are extensively cultivated, and pass them on to future generations. We hope that the economic integration studies found at the end of the inventory and the documentation studies conducted in basic sciences worldwide will now be carried out more effectively in Turkey and that the information presented will serve this purpose.

\section{Conflicts of Interests}

Authors declare that there is no conflict of interests

\section{References}

Başbağ, M., Hoşgören, H., \& Aydın, A. (2013). Vicia Taxa in the Flora of Turkey. Anadolu Tarım Bilimleri Dergisi, 28(1), 59-66.

Binzat, O. K. (2012). Revision of Vicia L. (Leguminosae) in Central Anatolia, Turkey. Ph.D. Thesis, Middle East Technical University, Institute of Natural and Applied Sciences, September, Ankara.

Bryant, J. A., \& Hughes, S. G. (2011). Vicia, Chapter 14, C. Kole (Ed.). Wild Crop Relatives: Genomic and Breeding Resources, Legume Crops and Forages, Heidelberg: Springer Verlag. 
Cremonini, R., Miotto, D., Api Ngu, M., Tota, D., Pignone, D., Blangiforti, S., \& Venora, G. (1998a). Cytology of Vicia species 5: nuclear chromatin structure, karyomorphological analysis and DNA content in newly discovered relatives of Vicia faba L.: Vicia kalakhensis Khattab, Maxted \& Bisby and Vicia eristalioides Maxted. Cytologia, 63, 371-379.

Cremonini, R., Ruffini, Castiglione, M., Venora, G., Blangiforti, S., Lo Savio, F. P., \& Pignone, D. (1998b). Cytology of Vicia species 6: nuclear chromatin organization, karyomorphological analysis and DNA amount in Vicia serratifolia Jacq. Caryologia, 51, 195-205.

Davis, P. H. (1970). Vicia L. Flora of Turkey and East Aegean Islands (Vol 3). Edinburgh, U.K.: Edinburgh University Press.

Emre, İ. (2011). Determination of Genetic Diversity in the Vicia L. (section Vicia) by Using SDS-PAGE. Pakistan Journal of Botany, 43(3), 1429-1432.

Enneking, D., \& Maxted, N. (1995). Narbon bean (Vicia narbonensis L.). Evolution of Crop Plants, 2. Ed. Smartt, J., Simmonds, N. W., London: Longman, 316-321.

Felsenstein, J. (1985). Confidence limits on phylogenies: an approach using the bootstrap. Evolution, 39, 783791.

Fennel, S. R., Powell, W., Wright, F., Ramsay, G., \& Waugh, R. (1998). Phylogenetic relationships between Vicia faba (Fabaceae) and related species inferred from chloroplast trnL sequences. Plant Systematics and Evolution, 212, 247-259.

Frediani, M., Sassoli, O., \& Cremonini, R. (1992). Nuclear DNA characterization of two species of Vicia: V. bithynica L. and V. narbonensis L. Biologia Plantarum, 34, 335-344.

Frediani, M., Maggini, F., Gelati, M. T., \& Cremonini, R. (2004). Repetitive DNA sequences as probes for phylogenetic analysis in Vicia genus. Caryologia, 57(4), 379-386.

Freeman, S., \& Herron, J. C. (1999). Evrimsel Analiz. Çıplak, B., Başıbüyük. H. H., Karaytuğ, S., \& Gündüz, İ. (Eds.). Palme Publishing, 28-29, 438-449.

Foladi, F. Z., Salimpour, F., Sharifnia, F., \& Ghanavati, F. (2013). Phylogenetic study of tribe Vicieae based on Internal Transcribed Spacer (ITS). Annals of Biological Research, 4(1), 75-79.

Gunn, C. R. (1980). Genus Vicia with notes about Tribe Vicieae (Fabaceae) in Mexico and Central America. United States Department of Agriculture, Printing Office Washington D.C. 20402, 1-48.

Inceer, H., \& Hayırlıoğlu-Ayaz, S. (2005). Giemsa C-banded karyotypes of Vicia cracca L. subsp. cracca and V. bithynica L. Turkish Journal of Botany, 29, 311-316.

Jaaska, V. (2008). Isozymes Evidence on the Specific Distinctness and Phylogenetic Position of Vicia incisa (Fabaceae). Central European Journal of Biology, 3(2), 169-176.

Kahraman, A., Binzat, O. K., \& Doğan, M. (2013). Pollen morphology of some taxa of Vicia L. subgenus Vicia (Fabaceae) Turkey. Plant Systematics and Evolution, 299, 1749-1760.

Kelchner, S. A. (2000). The evolution of non-coding chloroplast DNA and its application in plant systematics. Annals of the Missouri Botanical Garden, 87, 482-498. 
Kimura, M. A. (1980). Simple method for estimating evolutionary rates of base substitutions through comparative studies of nucleotide sequences. Journal of Molecular Evolution, 16, 111-120.

Kress, W. J., Liu, A.-Z., Newman, M., \& Li, Q. J. (2005). The molecular phylogeny of Alpinia (Zingiberaceae): a complex and polyphyletic genus of gingers. American Journal of Botany, 92(1), 167-178.

Kupicha, F. K. (1976). The infrageneric structure of Vicia L. Notes Roy Bot Garden Edinburgh, 34, 287-326.

Kupicha, F. K. (1981). Vicieae. In: Polhill, R. M. \& Raven, P. H. (Eds). Advances in Legume. Systematics, part 1. London: Ministry of Agriculture, Fisheries and Food, pp. 377-381.

Lefort, F., Lally, M., Thompson, D., \& Douglas, G. C. (1998). Morphological traits, microsatellite fingerprinting and genetic relatedness of a stand of elite oaks (Q. robur L.) at Trullynally, Ireland. Silvae Genetica, 47, 257-262.

Leht, M. (2009). Phylogenetics of Vicia (Fabaceae) based on morphological data. Feddes Repertorium, 120(7-8), 379-393.

Lorenzetti, F., Falcinelli, M., \& Veronesi, F. (1994). Miglioramento Genetico delle Piante Agrarie. Italy: Edagricole, p. 328.

Lorenzetti, F., Salvatore, C., \& Veronesi, F. (1996). Genetica Agraria. Italy: Patron, 456.

Maggini, F., Cremonini, R., Zolfino, C., Tucci, G. F., D'Ovidio, R., Delre, V., DePace, C., Scarascia Mugnozza, G. T., \& Cionini, P. G. (1991). Structure and chromosomal localization of DNA sequences related to ribosomal subrepeats in Vicia faba. Chromosoma, 100, 229-234.

Naranjo, C. A., Ferrari, M. R., Palermos. A. M., \& Poggio, L. (1998). Karyotype, DNA content and meiotic behaviour in five South American species of Vicia (Fabaceae). Annals of Botany, 82, 757-764.

Navratilova, A., Neumann, P., \& Macas, J. (2003). Karyotype Analysis of Four Vicia species using in situ Hybridization with Repetitive Sequences. Annals of Botany, 91, 921- 926.

Potokina, E. K., Tomooka, N., Vaughan, D. A., Alexandrova, T., \& Xu, R. Q. (1999). Phylogeny of Vicia (Fabaceae) based on analysis of RAPDs and RFLP of PCR amplified chloroplast genes. Genetic Resources and Crop Evolution, 46, 149-161.

Roze, I., \& Rurane, I. (2013). Revision of genus Vicia L. in the flora of Latvia, Acta Biologica Universitatis Daugavpiliensis, 13(1), 85-93.

Schaefer, H., Hechenleitner, P., Santos-Guerra, A., Menezes de Sequeira, M., Pennington, T. R., Kenicer, G., \& Carine, A. M. (2012). Systematic, biogeography, and character evolution of the legume tribe Fabeae with special focus on the middle-Atlantic island lineages. BioMed Central Evolutionary Biology, 12, 250.

Shaw, J., Lickey, E. B., Schilling, E. E., \& Small, R. L. (2006). Comparison of whole chloroplast genome sequences to choose noncoding regions for phylogenetic studies in angiosperms: the tortoise and the hare III. American Journal of Botany, 94(3), 275-288.

Simpson, M. G. 2012. Plant Systematics (2. Ed. ), Aytaç, Z., \& Kaptaner lğci, B. (Eds.), Ankara: Nobel Publishing. Small, R. L., Cronn, R. C., \& Wendell, J. F. (2004). Use of nuclear genes for phylogeny reconstruction in plants. Australian Systematic Botany, 17, 145-170. 
Soltis, D. E., Soltis, P. S., \& Milligan, B. G. (1992). Intra specific chloroplast DNA variation: systematics and phylogenetic implications. In: Soltis, P. S., \& Soltis, D. E. (Eds.) New York: Molecular plant systematics, Chapman and Hall, pp. 117-150.

Steele, K. P., \& Wojciechowski, M. F. (2003). Phylogenetic analyses of tribes Trifolieae, Vicieae, based on sequences of the plastid gene (matK) (Papilionoidae: Leguminosae). In: Klitgaard, B. B., \& Bruneau, A. (Eds). Advance in Legume Systematic, part 10, Higher Level Systematics, Royal Botanic Garden, Kew.

Taberlet, P., Gielly, L., Pantaou, G., \& Bouvet, J. (1991). Universal primers for amplification of three non-coding regions of chloroplast DNA. Plant Molecular Biology, 17, 1105-1109.

Tabur, S., Civelek, Ş., \& Bağcı, E. (2002). Cytotaxonomic studies on some Vicia L. Species Growing in the Eastern Mediterranean and Southern Aegean Regions II. Acta Botanica Hungarica, 44(1-2), 185-204.

Van de Wouw, M., Maxted, N., Chabane, K., \& Ford-Lloyd, B. V. (2001). Molecular taxonomy of Vicia ser. Vicia based on amplified fragment length polymorphisms. Plant Systematics and Evolution, 229, 91-105.

Venora, G., Blangiforti, S., Frediani, M., Maggini, F., Gelati, M. T., Ruffini, C. M., \& Cremonini, R. (2000). Nuclear DNA contents, rDNAs, chromatin organization and karyotype evolution in Faba section of the Vicia genus. Protoplasma, 213, 118-125.

Vural, M. (2000). Vicia L. In: Güner, A., Özhatay, N, Ekim, T., \& Başer, K. H. C. (Eds.). Flora of Turkey and the East Aegean Islands (Vol. 11), 89-92, Edinburgh: Edinburgh University Press.

Weber, L. H., \& Schifino-Wittmann, M. T. (1999). The Vicia sativa L. aggregate (Fabaceae) in Southern Brazil. Genetic Research and Crop Evolution, 46, 207-211.

White, T. J., Burns, T., Lee, S., \& Taylor, J. (1990). Amplification and direct sequencing of fungal RNA genes for phylogenetics. PCR Protocols: A Guide to Methods and Application, Innis, M., Gelfand, D., Sninsky, J., \& White, T. (Eds.). San Diego: Academic Press, 315-322. 